\title{
A Garamszentbenedeki alapítólevél helyneveinek névrendszertani vizsgálata*
}

1. A garamszentbenedeki apátságot I. Géza alapította meg 1075-ben. Az alapítás tényéről az apátság ugyanebben az évben keletkezett alapítólevele tanúskodik, mely megnevezi az apátság gazdag királyi adományait: az apátság birtokait, földjeit, vizeit, településeit, birtokainak határait, erdőit, szolgáit, kápolnáit (DHA. 1: 213-218). Az eredeti oklevél sajnos nem maradt ránk, azonban 1124-ben készítettek az eredeti alapján egy átiratot, majd erről készült egy újabb átirat 1217-ben (SzÖKE 2015: 23, DHA. 1:204-205). Ez az utóbbi maradt fent az utókor számára. Az alapítólevél átirata fontos nyelvemlékünk, ugyanis közel 280 helynévi szórványt tartalmaz, amelyböl az apátság birtokait mintegy 240 névadat jelöli meg. Gazdag szórványanyaga ellenére azonban ez az oklevél egészen a legutóbbi időkig alig került a kutatók érdeklődésének középpontjába. Ez részben azzal magyarázható, hogy a kutatók figyelme főképpen a hiteles oklevelek felé fordult, hiszen elsősorban ezekből tudunk kronológiailag is hiteles, megbízható következtetéseket levonni nyelvünk korabeli állapotára, helyesírására és egyéb jellemzöire vonatkozóan (SzÖKE 2015: 16).

A garamszentbenedeki apátság alapítólevelét nemcsak átirat jellege, hanem más körülmények miatt is nehéz vizsgálni. Az oklevelet ugyanis 1237 körül olyan részekkel bővítették ki, melyek az eredeti változatban még nem szerepeltek. Ezeket a betoldott részeket nevezzük interpolációknak. Az interpolált oklevelek sajátos helyzete abból fakad, hogy az átirat és a hamis oklevél jellemzőit is magukon hordozzák (SzÖKE 2015: 8). 1270 után tovább módosították az oklevél szövegét, s csökkenti a diploma hitelességét még az is, hogy az 1124-es és az 1217-es átirat lejegyzése csak jóval a megjelölt dátum után, 1270 körül történt meg (SzŐKE 2015: 23, 57). Nyelvtörténeti s azon belül névtörténeti elemzéseink során ezért két évszázadot is figyelembe kell vennünk: az eredeti oklevél keletkezésének idejét (a 11. századot), illetve a ránk maradt átirat interpolációjának az idejét (a 13. századot).

\footnotetext{
* A tanulmány az MTA-DE Magyar Nyelv- és Névtörténeti Kutatócsoport programja keretében és az NKFI 128270. számú pályázat támogatásával készült.
} 
A kutatók eltérő állásponton vannak abban a kérdésben, hogy mennyire használhatók, illetve használhatók-e egyáltalán az ehhez hasonló források a nyelv- és névtörténeti vizsgálatokban. A Garamszentbenedeki oklevél nyelvtörténeti forrásértékéről közzétett monográfiájában SzŐKE MELINDA ezzel összefüggésben azt emelte ki, hogy a hamis oklevelek, illetve az átiratok nem vizsgálhatók eredményesen a hiteles oklevelekre kidolgozott módszerekkel, hanem ezek speciálisan erre az oklevéltípusra kialakított módszertan alkalmazását követelik meg. Ennek révén azonban jó esélyeink lehetnek arra, hogy a bizonytalan kronológiai státuszú forrásokat is a nyelvtörténeti-névtörténeti kutatások szolgálatába állítsuk. Ez pedig azért különösen fontos, mert a magyar írásbeliség kezdeti időszakából csekély mennyiségü forrásanyaggal rendelkezünk, így a kutatóknak meg kell próbálniuk minden lehetséges forrást felhasználni. SzÖKE MELINDA fentebb idézett monográfiája e téren is fontos fordulópontot hozott. Ö mutatott rá ugyanis arra, hogy a nem hiteles források vizsgálata során kapott eredmények értékelése nagy körültekintést igényel, annál is inkább, mivel az átírások és a hamisítások célja sokszor a tulajdonjog meghamisítása volt. Ennek érdekében a hamisítók törekedtek a hamisított kor nyelvi sajátosságait visszaadni, így ha mindezt figyelmen kívül hagyjuk, a megírás korára és a hamisítás korára vonatkozó következtetéseink is torzulhatnak (SzŐKE 2015: 8, 21-22). A hamis, illetve az átírt oklevelek tulajdonnévi anyagának elemzéséhez ezek miatt a körülmények miatt is speciálisan erre a célra kifejlesztett módszerekre van szükség.

2. Amint azt a fentiekben kiemeltem, a Garamszentbenedeki alapítólevél nyelvi anyagát érintően két kronológiai síkot érdemes elkülönítenünk: az eredeti oklevél kiadásának idejét, azaz a 11. századot, illetve azt az időszakot, amikor az interpoláció megtörtént, vagyis a 13. századot. E két kronológiai síkot a Diplomata Hungariae Antiquissima címủ müvében GYÖRFFY GYÖRGY meg is kísérelte szétválasztani (DHA. 1: 212, lásd még Gy. 1: 418). Ehhez igyekezett olyan támpontokat is megadni, amelyek a kronológiai síkok elkülönítésében eredményesen vehetök figyelembe. E támpontok közül a legfontosabbakat az alábbiakban összegzem. Erre azért van szükség, mert a névtörténeti vizsgálat során is szem elött tartandó az, hogy egy-egy helynévi szórvány az oklevél 11. századi (eredeti) részéhez tartozik-e, s ezáltal felhasználható a 11. század nyelvének megismeréséhez, vagy pedig utólag került bele, ez esetben ugyanis az adott elem a 13. századhoz köthető kronológiai síknál veendő figyelembe, s erre a korra vonatkozóan szolgálhat forrásul a nyelvtörténeti kutatások számára.

Az apátság néhány hely birtoklásának ügyében perbe keveredett. GYÖRFFY elsőként ezt a körülményt használta fel az oklevélrészek és a bennük lévő nevek elkülönítéséhez, hiszen a perekre nem lett volna szükség, ha a kérdéses területek nevei az eredeti oklevélben is szerepeltek volna. Így tehát azok a nevek, melyek miatt az apátság perben állt, nagy valószínüség szerint csak később kerültek bele az oklevélbe. 
1209-ben készült egy pápai összeírás az apátság birtokairól. Mivel pedig ez a forrás az eredeti, 1075-ös oklevelet vette alapul, GYÖRFFY szerint azok a nevek, amelyek nem szerepelnek ebben az összeírásban, szükségszerüen az eredeti oklevélben sem szerepelhettek.

A településtörténet is nagy segítségünkre lehet annak megállapításában, hogy mely nevek kerültek bele később az oklevél szövegébe. A Garam völgyében három helységhez kapcsolódóan vámot is birtokolt az apátság (Goznica, Gelednek, Keresztúr). Ezek a települések az eredeti oklevél keletkezésének idején (1075ben) nagy valószínüséggel még ritkán lakott területeken feküdtek, így kétséges, hogy I. Géza éppen ezeket adományozta volna vámként az apátságnak.

Az elkülönítésben az is hasznunkra lehet továbbá, ha megvizsgáljuk a szövegben azt, hogy a lejegyző a 11 . vagy a 13 . században elterjedt latin szavakat használja-e a fogalmak lejegyzésére. Ezt a támpontot azonban körültekintően kell kezelnünk, hiszen - mint fentebb jeleztem — az átírás ténye maga is befolyásolhatta azt, hogy az oklevélíró melyik formával élt.

Nemcsak efféle külsődleges, hanem belső, tisztán nyelvtörténeti fogódzók is segítségünkre lehetnek az egyes szórványok kronológiai síkokhoz kötésében. Ilyen fogódzó lehet például az, hogy az adott elemek tartalmaznak-e véghangzót, hiszen a nyelvtörténészek véleménye szerint a véghangzók teljes eltűnése a 13. század közepére már lezajlott (E. ABAFFY 2003: 322). Erről a támpontról azonban maga GYÖRFFY is azt tartotta, hogy nem tekinthetjük teljes mértékben megbízhatónak. A véghangzó nélküli formák ugyanis nem feltétlenül azt mutatják, hogy ezek az alakok az interpoláció időszakában kerültek bele az oklevélbe, hiszen a véghangzók eltünése már az ösmagyar korban elkezdődött (BÁRCZI 1967: 108, 146, E. ABAFFY 2003: 321). Ez pedig azt jelenti, hogy véghangzó nélküli formák megjelenhettek a lejegyzésben már I. Géza idején is.

Egyes szórványok kronológiai hovatartozására az adott helynévi szórvány utótagja alapján is következtethetünk. A -falu utótag a 11. században ismereteink szerint még nem volt használatos, a településnevekben csak a 13. századtól vált jellemzővé, így a Mikolafalu és a Sárófalu szórványok esetében GYÖRFFY úgy gondolja, hogy ezek a településnevek az interpoláció időszakában kerülhettek bele az oklevélbe. A kérdésről több szakember is kifejtette a véleményét (ennek összefoglalását lásd SzŐKE 2015: 41), és ezek között az a SzÖKE MELINDÁtól származó elképzelés is szerepel, amely szerint az említett településnevek nemcsak az interpolációhoz köthetők, hanem az is előfordulhatott, hogy az eredeti oklevélben szereplő Mikola és Sáró egyrészes névformák egészültek ki az interpoláció alkalmával a -falu utótaggal. (E fogódzókról, támpontokról részletesebben lásd SzŐKE 2015: 41-43.)

Az itt röviden összefoglalt támpontok segítségével az oklevél eredeti szövegrésze és az interpoláció alkalmával utóbb bekerült szövegrészek megnyugtatóan 
szétválaszthatók (ehhez lásd DHA. 1: 204-212 és SzŐKE 2015: 56-66), így erre a névrendszertani elemzésben is bátran támaszkodhatunk.

3. A továbbiakban a Garamszentbenedeki alapítólevél helynévi szórványainak rendszertani elemzését helyezem a vizsgálataim középpontjába. Névrendszertani elemzést egy-egy oklevél kapcsán mások is végeztek már a korábbiakban: a Tihanyi alapítólevélről HOFFMANN ISTVÁN (2010: 226-232), a Tihanyi összeírásról és a Százdi alapítólevélről pedig KOVÁCS ÉVA közölt névrendszertani leírást (2015: 199-203, illetve 2018: 108-113). A Garamszentbenedeki alapítólevél esetében az analízis során SzŐKE MELINDA monográfiájára támaszkodtam. Ez a monográfia sok kérdést feldolgoz ugyan, és a helynévi szórványok alapos történeti-etimológiai vizsgálatát is elvégzi, de céljaiból adódóan (az oklevél nyelvtörténeti forrásként kezelése áll a középpontban) névrendszertani leírást nem tartalmaz. Az elemzésekben figyelmet fordítok arra, hogy az oklevél két kronológiai síkjához tartozó nevek bemutatását e kronológiai rétegek szerint végezzem el, rávilágítva arra is, hogy az adott időszakban a névrendszerben történtek-e szembetünő elmozdulások.

A Garamszentbenedeki alapítólevél helynévi szórványanyagának rendszertani alapú elemzéséhez az elméleti keretet a HOFFMANN ISTVÁN által kidolgozott több szempontú helynévvizsgálati modell (1993/2007) szolgáltatja. E modell megalkotása elött is készültek helynévelemzésre használatos tipológiai leírások (pl. BENKÖ 1947, LŐRINCZE 1947, KÁZMÉR 1957, INCZEFI 1970, KÁLNÁSI 1996), ezek azonban — részben éppen a sokféleségükből adódóan — nemigen alkalmasak arra, hogy a segítségükkel végzett helynévvizsgálatok eredményeit egymással megnyugtatóan összevethessük. Ennek elsősorban az a magyarázata, hogy mindegyik kutató a saját helynévanyagából kiindulva — azaz tisztán empirikus közelítésmóddal - hozta létre a tipológiáját. A korábbi elemzési modellekben emellett gyakran keveredett egymással a leíró és a történeti szempont, azaz bármennyire is fontosak a fent említett munkák a névkutatás történetében - nem alakult ki belölük egységes, koherens és ellentmondásoktól mentes szemléleti keret. A HOFFMANN ISTVÁN által kidolgozott helynévelemzési modell abban tér el az előbbiektől, hogy konkrét névanyag ismeretében ugyan, de elméleti alapon közelít a helynevekhez, s úgy igyekszik megalkotni több szempontú tipológiai leírását, hogy bennük az elemzési szintek és az azokhoz tartozó kategóriák egyértelműen elkülönüljenek, s a tipológia segítségével aztán ne csak az egyes helynévrendszerek váljanak leírhatóvá, hanem azok egymással is összehasonlíthatók legyenek. A modell lehetőséget biztosít arra, hogy használatával az egész magyar helynévrendszerről, annak bármely időszakbeli állapotáról, illetve a változásairól megállapításokat tegyünk. A leírási keret három elemzési szinten tartja a neveket elsődlegesen vizsgálhatónak: a leíró (szerkezeti) elemzés két szintje, a funkcionális-szemantikai és a lexikális-morfológiai szint mellett a keletkezéstörténeti 
elemzés különül el benne (lásd ehhez bővebben HOFFMANN 1993/2007: 53-162). Ezt a leírási keretet alkalmazták a fentebb említett nyelvemlékek rendszertani leírásához is a kutatók, ami azért lényeges szempont, mert ez a körülmény az eredményeket könnyedén összemérhetővé teszi.

A Garamszentbenedeki alapítólevél két kronológiai síkjához tartozó neveket egymástól elkülönítve elemzem, így van ugyanis leginkább lehetőségünk arra, hogy a két réteg között esetlegesen megmutatkozó névrendszertani eltéréseket kitapinthassuk. A Garamszetbenedeki alapítólevél közel 280 helynévi szórványt tartalmaz: ez 150 hely 156 névvariánsaként jelentkezik az oklevélben. Közülük azonban a névrendszertani elemzésbe — az alább kifejtett okok miatt — csupán 131 névformát tudtam bevonni: a 11. századi kronológiai síkot 82 név képviseli, a 13. századi kronológiai sík kapcsán pedig 49 elnevezéssel számolhattam.

Az elemzésbe bevonható nevek számának jelentős csökkentését több körülmény magyarázza. Egyrészt az, hogy ugyanazon nevek többszöri elöfordulásaira nem voltam tekintettel, az ilyeneket csak egyszer vettem figyelembe (bár az adataikat az elemzésben természetesen feltüntetem). Kizártam másrészt az analízisből azokat a neveket, amelyek olvasata, nyelvi azonosítása bizonytalan, s ezáltal az etimológiája megfejthetetlen. Az ilyen névadatok ugyanis névrendszertani szempontból egyáltalán nem, vagy csak bizonyos tekintetben (például a névstruktúra kérdésében) hasznosíthatók. A Gcohlu, Zebeli, Zirega és Wolue adatok esetében például csak a név szerkezetét (egyrészes vagy kétrészes név) és a szövegkörnyezet alapján a jelölt hely fajtáját (természeti vagy müveltségi név) tudjuk megállapítani. Az Archisti, Lughta és Unuri adatok (és szövegkörnyezetük) még erre sem nyújtanak lehetőséget, így ezekkel az adatokkal a névrendszertani vizsgálataim során egyáltalán nem számoltam.

Kizártam a névrendszertani elemzésből néhány olyan adatot, amelyek csak latinul szerepelnek az oklevélben. Nem került bele az elemzésbe ezért az Erdély megjelölésére használatos Ultra silvam adat. A Sancti Benedicti és Sancti Martini adatok több szempontból is problematikusak, hiszen valószínüleg inkább a templom védőszentjére utaltak csupán (s a templom megjelölései voltak a forrásban), ilyen módon pedig az sem tudható ezekről az adatokról, hogy magyar helynévként használatosak voltak-e az adott korban. A latin közszó és genitivusban álló személynév kapcsolatából álló adatokat szintén figyelmen kívül hagytam. A puteum Dirsidi, sepulturam Gunreidi, puteum Hotuandi és sepultura Uetcudi adatok tulajdonnévi státusa, helynév volta erősen kérdéses: ezek a latinosított megjelölések az adott hely közszói körülírásai is lehetnek. Az említetteken kívül további olyan latin adatok is előfordulnak az oklevélben, amelyek ugyancsak a tulajdonnévi, helynévi státuszuk bizonytalan volta miatt mellőzendők: a villam Bissenorum és a monte presbiteri előfordulások például ilyenek. Más esetekben azért nem tudunk egyes adatokat megbízhatóan bevonni az elemzésbe, mert a 
latin említések többféle magyar névformát is rejthetnek. Bár a villa Martini adat mögött jó eséllyel gyaníthatunk magyar településnevet, mégsem számoltam ezzel az adattal, mert Márton, Mártoni és Mártonfalva típusú magyar nevet egyaránt rejthet a latin fordítás. Noha hasonló probléma jelentkezik a Nove Civitatis említés esetében is, ezt az adatot mégis hasznosítani tudtam a kétrészes településneveknél, mivel csak annyi a kérdéses, hogy Újváros vagy Újvár névformát takar-e a latin megjelölés, a kétrészes településnévi jellege nem vitatható.

Vannak azonban olyan, az alapítólevélben csakis latinul jelentkező nevek, amelyek annak ellenére, hogy latin formában szerepelnek, mégis bekerültek a névrendszertani elemzésbe. Ezek a nevek a Duna (Danubium, Danubii, Danubio), a Garam (Gran, Grane, Grana) és a Fehérvár (Alba) elnevezések, melyekröl más források alapján tudjuk, hogy biztosan voltak magyar megfelelöik, s azok nyelvi szerkezete is egyértelmü, így pedig a névrendszertani elemzéshez is hasznosítani tudjuk őket (mégpedig Duna, Garam és Fehérvár néven elemezve). A latinizáló, de magyar névformából létrehozott nevekkel szintén számoltam a névrendszertani vizsgálat során, hiszen maguk a latinizált formák tanúskodnak a magyar névformák létéről: pl. Strigoniensi Esztergom megjelölésére, Colocensi Kalocsa elöfordulásaként. A félfordításokat is igyekeztem hasznosítani a névrendszertani elemzés szempontjából. Ez két helynevet érint, a Nagy-Alpár (maioris Alpar) és a Nagy-Szék (magnam Zecum) neveket, amelyeket kétrészes magyar nevekként vettem figyelembe. Azon nevek, amelyek a magyar formájuk mellett latinra fordítva is bekerültek az oklevélbe, nem okoztak nehézséget, hiszen a magyar formákra az elemzés során biztosan támaszkodhattam: piscina Rotunda és Kerektou; Lutea piscina és Sarustou (vö. SzÖKE 2015: 174). Ezeket a körülményeket mérlegelve állt egybe végül az a 131 nevet tartalmazó állomány, amire alapozva a rendszertani leírást elvégeztem.

4. A névrendszertani leírás során mindenekelött érdemes figyelemmel lennünk arra, hogy természeti vagy müveltségi nevekre vonatkozik-e az elemzésünk, ezek létrejöttét ugyanis nem ugyanazok a tényezők befolyásolják (HOFFMANN-RÁCZTÓTH 2018: 117). A természeti nevek közé az ember változtató tevékenységén kívül eső helyek neveit szokás sorolni, a műveltségi nevekhez pedig az ember alkotásainak helynévszerü megnevezéseit. Természeti névnek tekinthetők például a víznevek, az erdők, hegyek, völgyek stb. nevei, míg a falvak, városok, utak megnevezései, az épületek, településrészek stb. nevei a müveltségi nevek közé tartoznak. Az 1. ábrán az oklevél mủveltségi és természeti neveinek a megoszlása látható.

A rendszertani vizsgálatok első lépéseként azt mutatom be, hogy az oklevél eredeti, 11., illetve interpolált, 13. századi rétegében milyen műveltségi és természeti nevek szerepelnek (a névfajták részletes analízisét azonban nem itt, hanem írásom egy későbbi pontján végzem el). Az adatközlésben a problémás olvasatú 
neveket, névrészeket? követi. Az ejtésvariánsokat ( ) jelzi. Ha a névnek a forrásban latin vagy latinizáló alakja szerepel, akkor a magyar névalakot [ ] fogja közre. A címszavak után zárójelben, dőlt betűkkel olvasható a nevek oklevélbeli előfordulása. Amennyiben egy név többféle lejegyzéssel is szerepel az oklevélben, akkor azokat itt mind feltüntetem. Az adatok közlésében, illetve a nevek címszóalakjának meghatározásában SzŐKE MELINDA munkájának szövegközlésére és szótári egységére támaszkodtam (vö. 2015: 43-56, 155-208).



1. ábra. A müveltségi és a természeti nevek aránya az oklevél eredeti és interpolált részében

A müveltségi neveket a Garamszentbenedeki oklevélben (ahogyan a legtöbb korabeli forrásban) jórészt a birtokok, települések nevei képviselik. Az oklevél 11. századi rétegében az alábbi müveltségi nevek szerepelnek: [Alpár] (Alparienses) Bars (Borsu, Bors), Besenyőd(i) (Besenendi), Bőd (Benildi), Csany (C(hon)u, Chonienses, Chonu), Csejt(i) (Cehti), Dobo(s)z (Duboz), Füzegy (Fizegi, Fizeg), Gég (Gegu, Gegnienses), Győgy (Gehgi), [Kalocsa] (Colocensi), Keszteg (Caztech), Kesztölc (Kestelci), Lél (Lelu), Ludány (Ludan), Melényhalom ? (Melinhalmu), Mélyér (Meler), Pél(y) Pelő (Pelu), Pográny (Pagran), Sági (Sagi), Sáp(i) (Sapi), Szanda (Zunde), Szántó (Samto), Szoboszlóvásár (Zobuzlou wasar), Szolnok (Zounuk), Szőlős (Sceulleus), Taszár (Tazzar), [Udvard] (Hudwordiensium), [Újváros] (Nove Civitatis), Varsány (Wossciani, Wosscianorum), Zsemlér (Semlar), Zsikva (Sikua). Település és egyben vár elnevezéseként állnak a következő névalakok: Bihar (Bichor, Bichari), [Csongrád] (Cernigradenses, Cernigradensium), [Esztergom] (Strigoniensi), [Fehérvár] (Albensium), Komárom (Camarun, Camarienses), [Vác] (Wacensis).

$\mathrm{Az}$ oklevél interpolált, 13. századi rétegében az alábbi müveltségi nevek tünnek fel, ugyancsak birtokok és települések neveiként: Baka (Baka), Bálvány 
(Balwan), Belleg (Bilegi), Braján (Braian), Füss (Fius), Geletnek (Gelednuk), Goznica (Goznucha), Kakat (Kokot), Keresztúr (Kerestur), Knyezsic (Knesecz, Kenesech), Kovácsi (Kouachi), Kürt (Kurth), Mikolafalu (Mikolafalu), Rikács(i)ártánd (Rikachiartand), Sári (Sari), Sárófalu (Saroufalu), Tajna (Taina), Tolmács (Talmach), Torda (Turda).

A természeti nevek névfajták szerinti megoszlása jóval színesebb képet mutat. A természeti nevek között az oklevél 11. századi síkjában legnagyobb számban vízneveket (folyóvizek, állóvizek, vízzel kapcsolatos egyéb helyek megnevezései) találunk: Aranyos (Aranas, Aureus), Árok (aruch), Bokor (Bocur), [Duna] (Danubium, Danubii, Danubio), Füzegy (Fizegi, Fizeg), [Garam] (Gran, Grana, Grane), Kompa (Compa), [Körös] (Crys), Kurca (Curice, Curicea), Ladoméra (Radmera), Mély-ér (Meler), [Nagy]-Alpár (maioris Alpar), Nyitra (Nitra), Sarok? -ér (Surchuer), Tepla (Tapla), [Tisza] (Tiza (m), Tize, Ticia), Torna (Tornova), Ug-ér Huku-ér (Hucu, Huger), Vág (Wag), Vajas-ér (Woioser), Zsikva (Sikua); Csany-tó (Cunutou), Fige (Fige), Kerek-tó (piscina Rotunda, Kerektou), Kondora (Cundura), [Nagy]-Szék (magnam Zecum), Szil (Scilu), Szirega ? (Zirega); Kengyel (Kengelu), Keskeny (Kesekun), Pata ? (Pote), Szék (Zecu), Vág töve (Wagetuin), Zsitva töve (Sitouatuin). Kiemelkedések neveire jóval ritkábban akadunk ebben a kronológiai rétegben: Gyúl (Gcohlu), Naszály (Nazal), Saruly (Sorul), Taka (Taka); völgyet jelöl meg a Szebély ? elnevezés (Zebeli); erdők neveként állnak a Sosolgy (Susolgi) és a Tergudi (Tergudi) elnevezések.

Az oklevélbe az interpoláció alkalmával természeti nevek ugyancsak bekerültek. A 13. századi réteghez kapcsolható természeti nevek között is a vízre utaló névadatok vannak jelen a legnagyobb számban: Fenyö-sevnice (Feniosaunicza), Gáj (Gai), Lis(z)na (Lisna), Prestuc Prisztuc (Prestucz), Sarac(s)ka (Sarraczka), Tormás (Tarmas), Zsitva (Sitoua(m)); Ecse ? tava (Ecetoua), Egres (Egres), Eperjes (Haperies), Ér töve (Ertue), Fehér-tó (Feirtou), Fül ? (Filu), Halastó (Halastou), Horgas (Horgas), Hosszú-ér (Hosiouer), Kék-tó (Kektou), Kis-Tisza (Kustiza), Köbi ? (Keubi), Nándor-tó (Nandurtou), Osztora (Ostra), Ördög ? sara (Orduksara), Sáros-tó (Lutea piscina, Sarustou), Sokord (Sokord), Sulymos (Sulmus), (Wolue) (Wolue). Kiemelkedést jelölnek a Csúz (Chus), Plesivice (Plesiuicze), Vidricki (Wydrizki) nevek; erdőként szerepel a Szurkos ? -cser elnevezés (Surkuscher).

Ahogyan az az 1. ábráról leolvasható, a Garamszentbenedeki alapítólevél eredeti részéhez tartozó neveknek az 52\%-a természeti név, 48\%-a pedig müveltségi név. A két fö helynévfajta tehát közel azonos arányban van jelen az oklevél ezen részében. Az oklevél interpolált részében található helyneveknek ellenben a 61\%-a tartozik a természeti nevek közé, s a neveknek csupán a 39\%-a műveltségi név. A természeti és müveltségi nevek arányában a két oklevélrész tehát nagy eltérést jelez. A természeti nevek magasabb arányú jelenléte a 13. századi oklevélrészben 
azzal a körülménnyel áll összefüggésben, hogy az interpoláció során a birtokokat a határleírásukkal együtt rögzítették, illetve több, az oklevélben már eleve szereplő birtokot a határleírásukkal kiegészítve említettek, s ez az eljárás azzal az eredménnyel járt, hogy a 13. századi interpoláció során több természeti névvel gazdagodott az alapítólevél (vö. SzŐKE 2015: 69-79).

5. A garamszentbenedeki apátság alapítólevelében szereplő helynevek névrendszertani elemzése során fontos bemutatnunk a két kronológiai sík kapcsán az egyrészes és a kétrészes helynevek arányát is. A helynevek ugyanis az itt alkalmazott elméleti keretben csak egy- vagy kétrészesek lehetnek. Egyrészesnek akkor tekinthető egy helynév, ha benne a megnevezett helyre vonatkozóan csak egyetlen szemantikai jegy fejeződik ki, míg a kétrészes nevek két információt árulnak el az adott helyről. Egyrészes tehát például az Eperjes halastó neve, a Hosszú-ér viszont kétrészes névformának tekintendő, mivel a hely kiterjedésére (hosszú) és a hely fajtájára (ér) is történik utalás benne. A 2. ábra a két névstruktúra arányát mutatja be az eredeti és az interpolált oklevélrészben.

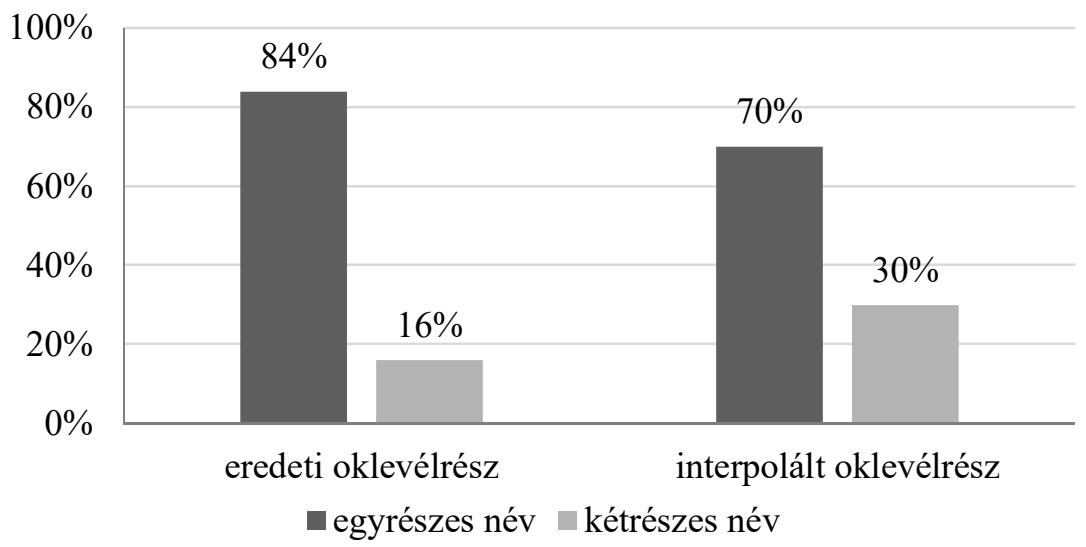

2. ábra. A névszerkezeti típusok megoszlása az oklevél eredeti és interpolált részében

Amint az a 2. ábrán egyértelmüen látható, az oklevél eredeti részében és az interpolált nevekkel kiegészült részében is az egyrészes nevek dominálnak. A Garamszentbenedeki alapítólevél eredeti, 11. századi szövegében található helyneveknek a 84\%-a egyrészes névforma (pl. Besenyödi, Kengyel), a kétrészes nevek aránya pedig 16\% (pl. Csany-tó, Szoboszlóvásár). Az oklevélbe a 13. században betoldott részek helynevei körében $70 \%$ az egyrészes nevek aránya (pl. Füss, Sári), míg a kétrészes elnevezések 30\%-ot tesznek tesznek ki (pl. Kis-Tisza, Rikács(i)ártánd). Ezeket az összefoglaló számadatokat ugyanakkor érdemes valamelyest differenciáltabban néznünk, s a korábban elkülönített fö helynévfajtákra is figyelemmel lennünk a névszerkezeti jellemzőket illetően is. A következőkben ezért külön tárgyalom a müveltségi és a természeti nevek névszerkezeti és szemantikai jellemzöit, továbbra is ügyelve a két kronológiai réteg elkülönítésére. 


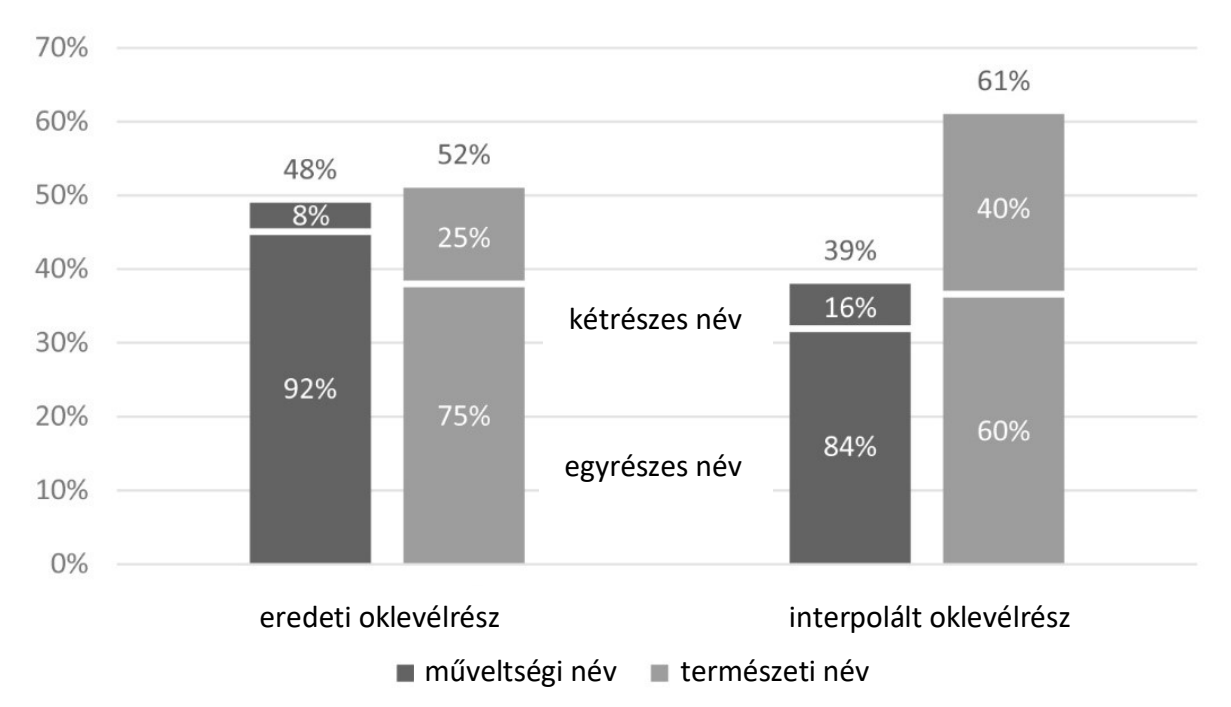

3. ábra. Az egy-és kétrészes nevek megoszlása a természeti és a müveltségi nevek körében az oklevél eredeti és interpolált részében

5.1. Az oklevél eredeti részében szereplő müveltségi nevek $92 \%$-a egyrészes. A 11. századi egyrészes müveltségi nevek többsége a hely birtokosára utal, mint például a Böd, Csany, Gég és Ludány nevek. Funkcionális-szemantikai szempontból ezek a nevek képviselik a leggazdagabb csoportot, hiszen a 35 egyrészes müveltségi név több mint felét (51\%-át) teszik ki. Ez a magas arány azzal a már korábban említett körülménnyel magyarázható, hogy a müveltségi nevek többnyire birtokok, települések megnevezései, és ezeket a helyeket gyakran a birtokosuk után nevezték el. A hely birtokosa mellett az ott lakó emberek is szolgálhatnak a névadás motivációjaként, bár az ilyen típusú nevek jóval kisebb számban találhatók meg a Garamszentbenedeki alapítólevél 11. századi részében. Négy ilyen név szerepel az oklevélben: a népnevet tartalmazó Besenyőd(i), esetleg a Csejt(i), ${ }^{1}$ Varsány ${ }^{2}$ és a foglalkozásnévi Szántó, ez az egyrészes müveltségi nevek $11 \%$-át fedi le. Jelentősnek mondható még az egyrészes műveltségi nevek körében a megnevező funkciót betöltő elnevezések (más nyelvből átkerült jövevénynevek) kategóriája: Csongrád, Esztergom, Kesztölc, Pográny, Taszár, Zsemlér (17\%). A hely más helyhez való viszonyát fejezik ki a Füzegy, Melényhalom, Mélyér, Sági és Zsikva nevek (14\%). Egyéb funkcionális-szemantikai jellemző is

\footnotetext{
${ }^{1}$ A név összefüggésbe hozható ugyan a cseh népnévvel, de valószínübb, hogy személynévi eredetű az elnevezés (SzÖKE 2015: 162).

${ }^{2}$ A Varsány név a honfoglalás előtt a magyarsághoz csatlakozott alán (jász) néptöredék nevének többes számából alakult (SzÖKE 2015: 206).
} 
megjelenik szórványosan egy-két névben: a Szölős név az ott levő növényzetre vagy szőlömüvesekre, az Udvard név pedig az ott levő épületre, udvarházra utal.

A 11. századi müveltségi nevek között mindössze három kétrészes elnevezést találunk (bár közülük kettő csak latinul szerepel az oklevélben). A Fehérvár névforma 'fehér színü vár', Újváros 'a környezeténél újabb település', Szoboszlóvásár pedig 'egy bizonyos Szoboszló nevü személy vásáros faluja' formában írható le szemantikai szempontból.

Az interpolált oklevélrészben szereplő müveltségi nevek 84\%-a egyrészes. Közöttük szintén a hely birtokosára utaló nevek képviselik a legjelentősebb arányt (31\%), bár ez közel sem olyan kiugróan magas, mint azt az eredeti oklevélrészben láthattuk. A Baka, Belleg, Kakat, Tolmács és Torda nevek fejeznek ki a hely birtokosára való utalást. A Geletnek, Goznica, Knyezsic és Tajna településnevek mint jövevénynevek megnevező funkcióban állnak. Egyéb szemantikai jegy szórványosan jelentkezik csak a 13. századi réteg egyrészes településnevei körében. Az ott lakó emberek foglalkozására utal a Kovácsi, a törzsi hovatartozás emlékét örzi a Kürt elnevezés. A Szent Kereszt tiszteletére szentelt templom állt Keresztúr-on, és talán az ott lévő növényzetre utalhat a Füss (azaz 'füves, füs') elnevezés. A Bálvány, Braján és Sári nevek esetében többféle névadási motiváció is felmerülhet, ezek szemantikai szerkezetét ezért nem lehet egyértelműen meghatározni.

A 13. századi műveltségi nevek között kétrészesek az előtagjukban a település birtokosára utaló Mikolafalu és Sárófalu nevek. Kétrészes továbbá a Rikács(i)ártánd név, mely az Ártánd nevü település Rikács melletti fekvését fejezi ki (SzÖKE 2015: 190).

5.2. A 11. századi természeti nevek háromnegyede egyrészes, s ezek igen jelentős hányada (80\%-a) víznév. A 11 . századi egyrészes természeti nevek csaknem fele megnevező szerepben álló jövevénynév: Duna, Garam, Kompa, Körös, Kurca, Naszály, Nyitra, Tepla, Tisza, Torna, Vág, Zsikva. A hely birtokosára utaló nevek is megjelennek, de számuk nem olyan jelentős, mint a müveltségi nevek esetében, ahol a birtokok kapcsán fontos tulajdonviszonyt megerősítő szerepet tölthetett be az, ha a birtoknak és a tulajdonosának a neve azonos volt. A természeti nevek körében a birtokosra utalnak a Kondora, Pata, Taka és Tergudi nevek. A hely fajtáját jelöli meg az Árok és a Szék elnevezés, mindkettő vízrajzi név. A Kengyel és a Keskeny nevek a hely alakjára, a Füzegy és a Szil víznevek pedig az ott levő növényzetre utalnak. Az Aranyos víznévben a hely anyaga tükröződik, a Bokor víznév a mellette fekvő Bokor településről kaphatta a nevét. A szemantikai elemzés szempontjából bizonytalanul (többféleképpen) ítélhetők meg a Fige, Ladoméra és Saruly nevek; a Gyúl, Sosolgy, Szebély és Szirega név motivációs hátterét pedig nem ismerjük. 
A természeti nevek közül 41 található az eredeti oklevélrészben (58\%), negyedük kétrészes elnevezés: a Csany-tó, Kerek-tó, Mély-ér, [Nagy]-Alpár, [Nagy]Szék, Sarok? -ér, Ug-ér Huku-ér, Vág töve, Vajas-ér és Zsitva töve. A részfordításos [Nagy]-Alpár és a [Nagy]-Szék, illetve a Mély-ér nevek a hely méretére utalnak. Település melletti fekvés tükröződik a Csany-tó és az Ug-ér $\sim H u k u$-ér víznevekben. A Vág töve és a Zsitva töve nevek a folyó torkolatát nevezik meg. Alakjáról nevezték el a Kerek-tó halastavat, a Vajas-ér halászóhely pedig a zsíros felszínü vize után kapta a nevét. A Sarok-ér elnevezés mögött rejlő névadási szándék ma már nem deríthető fel.

A természeti nevek közül 30 szerepel a 13. századi, interpolált oklevélrészben (42\%). Közülük 18 egyrészes elnevezés (60\%). Ezek egy részéhez az ott lévő növényzet szolgáltatta a névadási indítékot: Egres, Eperjes, Sulymos, Tormás. A Gáj, Plesivice és Zsitva jövevénynevek megnevező szerepben állnak. Ugyancsak megnevező szerepüek lehetnek a Lis(z)na, Osztora, Prestuc $\sim$ Prisztuc és a Sa$r a c(s) k a$ nevek is, amennyiben ezek szintén szláv eredetü jövevénynevek, de esetükben más szemantikai tartalom (belső névadás) is feltételezhető. Birtoklásra utalhat a Csúz név, a Horgas halastó pedig a víz alakjáról (vagy esetleg a halászat során használt horogról) kaphatta a nevét. A Fül, Köbi, Sokord, Vidricki és Wolue nevek funkcionális-szemantikai háttere nem deríthető fel, az utóbbinak az olvasata sem világos.

A 13. századi természeti nevek között szép számmal találunk kétrészes neveket is (40\%), az előtagjukban sokféle szemantikai tartalommal. A tó vizének színe tükröződik a Fehér-tó és a Kék-tó elnevezésekben. A Hosszú-ér víznév a hely méretére, a Halas-tó név pedig (amennyiben kétrészes névként tekintjük) a hely funkciójára utal. Az adott hely anyaga fejeződik ki a Sáros-tó névben. Birtokosra utal az Ecse tava név, növényzetre a Fenyö-sevnice. Lokális viszony jelenik meg az Ér töve és a Kis-Tisza névben. A Nándor-tó, Ördög sara és a Szurkos-cser nevek többféle szemantikai jegyet is kifejezhetnek. Legvalószínübbnek az tartható, hogy a Nándor-tó a nándor népnévről vagy a Nándor településnévről kapta a nevét: az előbbi esetben az ott lakókra, az utóbbi esetben pedig lokális viszonyra utalva. Az Ördög sara név az ördög és a sár fönevek összetételével keletkezett: az ilyen nevek szemantikai szerkezete nem egészen egyértelmü (vö. az Ördögárok típusú nevek szerte a Kárpát-medencében). A Szurkos-cser pedig (amennyiben helyes az olvasat) a szurok 'gyanta' jelentésü főnevet és a cser fanevet tartalmazza, de felvethetö az is, hogy a szurokfü növényről kapta a nevét az erdő: a csererdő fáinak jellemzőjére vagy az aljnövényzetre utalva.

5.3. A Garamszentbenedeki alapítólevél helyneveinek funkcionális-szemantikai elemzéséből a fentiek alapján a következő fontosabb tanulságokra, tendenciákra mutathatunk rá. Az oklevél műveltségi nevei csaknem kivétel nélkül birtokokat, településeket neveznek meg, e névfajta egyedei néhány névtől eltekintve 
mindkét kronológiai síkon egyrészesek, és jelentős arányban a település birtokosának nevét viselik. A természeti nevek leggyakrabban álló- vagy folyóvizek megnevezései, és bennük sokféle szemantikai tartalom jelenik meg. Az analízis a felszínre hozta azt is, hogy a 13. századi oklevélrészben jelentősen megnőtt a kétrészes nevek aránya, ami a természeti nevek arányának növekedésével magyarázható. Feltünő változás ugyanis, hogy míg az eredeti, a 11. századi oklevélrészben a természeti neveknek csak az egynegyede kétrészes, az interpolált, a 13. századi oklevélrészben a természeti nevek esetén ez az arány már 40\%-ot tesz ki. A kétrészes nevek aránya — jóval kevesebb névadat mellett ugyan — a müveltségi nevek körében a duplájára (8\%-ról 16\%-ra) nőtt.

6. A Garamszentbenedeki alapítólevél helyneveinek névrendszertani tanulságait érdemes összevetni más oklevelek ilyen természetü vizsgálatának az eredményeivel. A Garamszentbenedeki alapítólevél eredeti oklevélrésze a Tihanyi alapítólevéllel (1055) és a Százdi alapítólevél 11. századi részével (1067), interpolált része pedig a Tihanyi birtokösszeírással (1211) és a Százdi alapítólevél 13. századi részével (1276) hasonlítható e szempontból össze. Az alábbiakban ezt az összevetést végzem el, csakis a főbb jellemzőkre térve ki, és az írásomban a fentiekben alkalmazott szempontokat követve.

A müveltségi és a természeti nevek viszonyát tekintve azt láthatjuk (4. ábra), hogy a két helynévfajta aránya a Garamszentbenedeki alapítólevél eredeti oklevélrészében közel azonos (48-52\%), a Tihanyi alapítólevélben ez az arány a nagy valószínüséggel tulajdonnévként értékelhető adatokat figyelembe véve hasonló az előzőbbihez (47-53\%), ${ }^{3}$ a Százdi alapítólevél 11. századi részében pedig a müveltségi nevek magas aránya figyelhető meg (73-27\%). A Garamszentbenedeki alapítólevél interpolált nevei között a természeti nevek vannak többségben (61\%), a Százdi alapítólevél 13. századi részében pedig éppen fordított képet látunk, a müveltségi nevek fordulnak elő nagyobb arányban (67\%), míg a Tihanyi birtokösszeírás nevei között a természeti és müveltségi nevek aránya kiegyensúlyozott (50-50\%). Ezek a jellemzők persze föként azzal vannak összefüggésben, hogy egy-egy oklevélben (vagy oklevélrészben) milyen „stratégiával” rögzítették a birtokok neveit: felsorolásszerüen vagy a határjárásukkal együtt. Ez utóbbi esetben - mint láthattuk - a természeti nevek aránya is nagyobb az adott forrásban. Hosszabb időtávra vonatkozóan azonban ez a szempont is tanulságos eredményeket hozhat: jól mutatja ugyanis az oklevélírás gyakorlatának alakulását.

\footnotetext{
${ }^{3}$ Ha azonban az összes szórványadatot vesszük figyelembe, ez az arány 40-60\%-ra módosul.
} 


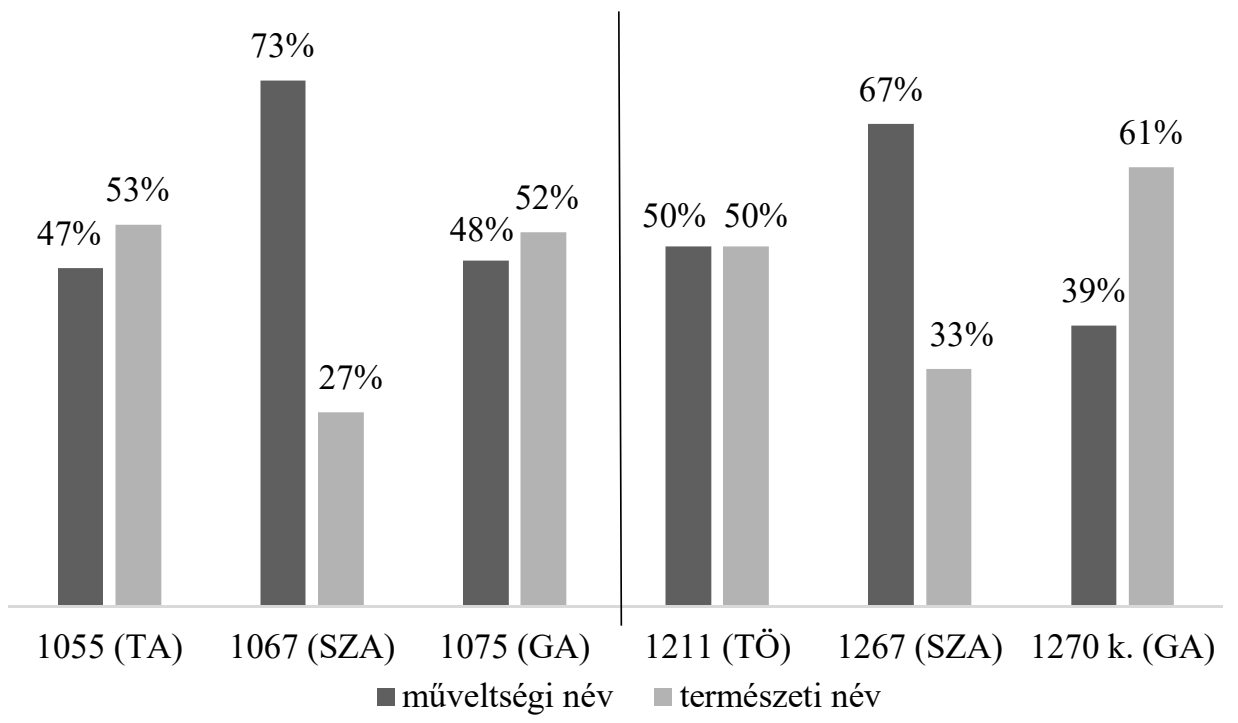

4. ábra. A természeti és a müveltségi nevek aránya a vizsgált oklevelekben

A müveltségi nevek (közülük kiemelten csak a településnevek) 5. ábrán látható összevetéséből az a tanulság fogalmazható meg, hogy a településnevek mindegyik oklevélben túlnyomó többségben (a Százdi alapítólevél 11. századi részében kizárólag) egyrészesek. E névfajta egyedei közül a legnagyobb arányban a Garamszentbenedeki alapítólevél interpolált része tartalmaz kétrészes településneveket.

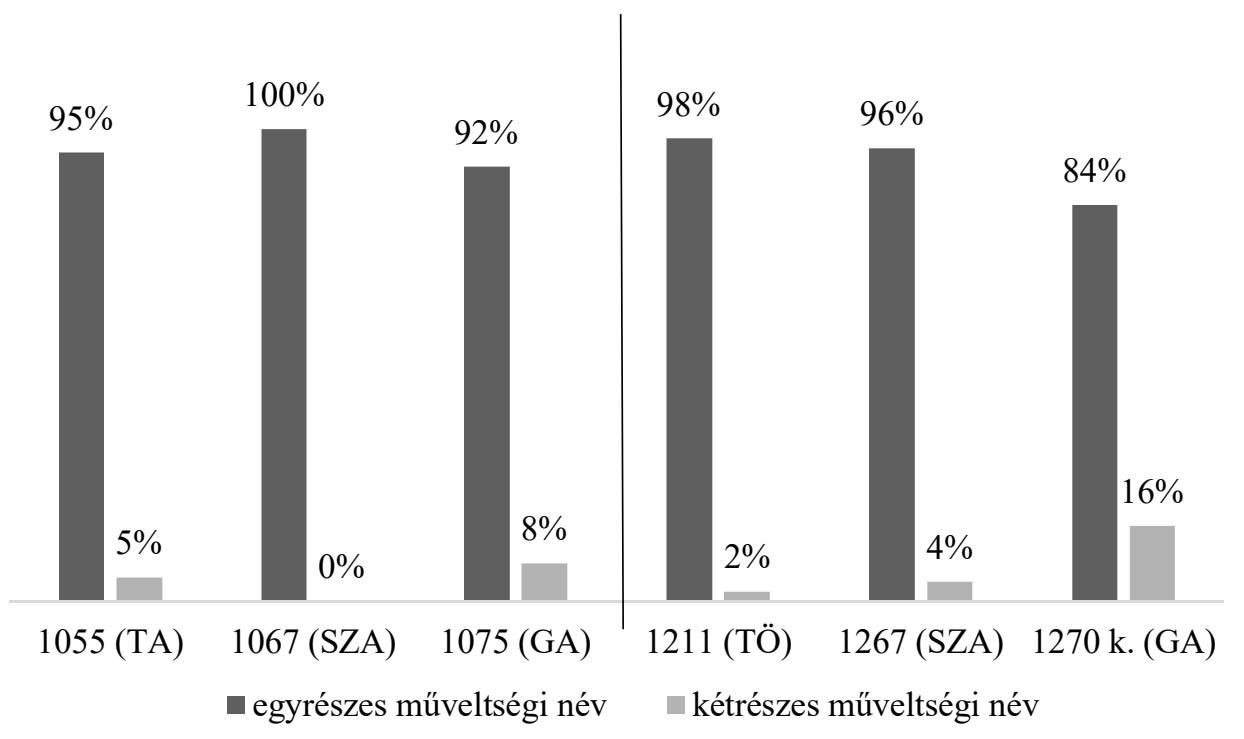

5. ábra. Az egyrészes és kétrészes településnevek aránya a vizsgált oklevelekben 
A természeti nevek szerkezetét vizsgálva kiegyensúlyozottabb kép tárul elénk. A 6. ábra legfőbb tanulságait abban összegezhetjük, hogy a Tihanyi alapítólevél kivételével mindegyik forrásban az egyrészes természeti nevek vannak többségben, de ez a fölény jobbára csak mérsékelt a kétrészesekkel szemben. Feltünően különbözik a fő tendenciáktól egyrészt a Tihanyi alapítólevél, ahol a kétrészes természeti nevek nagyfokú dominanciáját tapasztaljuk, másrészt a Garamszentbenedeki alapítólevél mindkét kronológiai síkja, ahol viszont minden forrásnál nagyobb arányúnak mutatkozik az egyrészesség a természeti nevek esetében. Ennek a hátterében az a körülmény is ott áll, hogy az oklevél nagy számban tartalmaz — az apátság és birtokai földrajzi helyzetéből adódóan — jövevényneveket (elsősorban szláv eredetủ vízneveket), amelyek pedig a magyar helynévrendszer elemeiként minden esetben egyrészesek.



6. ábra. Az egyrészes és kétrészes természeti nevek aránya a vizsgált oklevelekben

Az 5. és 6. ábra együttes elemzése azt is jelzi egyébként, hogy míg az egyrészes természeti nevek a Garamszentbenedeki alapítólevélben képviselnek legmagasabb arányt, a településneveket tekintve pedig épp ebben az oklevélben találjuk — bármely kronológiai síkot nézzük is - a legtöbb kétrészes névformát.

Az elemzések legfontosabb tanulságaként végül arra mutathatunk rá (s ezt jól tükrözi az 5-6. ábra), hogy a 11-13. század időszakában a magyar helynévrendszer karakterét a településnevek egyrészessége határozta meg, a természeti nevek esetében viszont a két névszerkezeti modell alapvetően kiegyensúlyozott képet mutat, bár ettől vidékenként lehettek akár nagyobb mértékü eltérések is. 


\section{Irodalom}

E. ABAFFY ERZSÉBET 2003. Az ómagyar kor. Hangtörténet. In: KISS JENŐ-PUSZTAI FERENC szerk. Magyar nyelvtörténet. Budapest, Osiris Kiadó. 301-351.

BÁRCZI GÉZA 1967. Hangtörténet. In: BÁRCZI GÉZA-BENKÖ LORÁND-BERRÁR JOLÁN, A magyar nyelv története. Budapest, Tankönyvkiadó. 95-180.

BENKŐ LORÁND 1947. A Nyárádmente földrajzinevei. A Magyar Nyelvtudományi Társaság Kiadványai 74. Budapest.

DHA. = GYÖRFFY GYÖRGY föszerk. 1992. Diplomata Hungariae Antiquissima. Vol. I. Budapest.

Gy. = GYÖRFFY GYÖRGY 1963-1998. Az Árpád-kori Magyarország történeti földrajza $I-I V$. Budapest, Akadémiai Kiadó.

HoffMANn IsTVÁn 1993/2007. Helynevek nyelvi elemzése. Debrecen, Debreceni Egyetem Magyar Nyelvtudományi Tanszék. Második kiadás: Budapest, Tinta Kiadó, 2007.

HoFFMANN ISTVÁN 2010. A Tihanyi alapitólevél mint helynévtörténeti forrás. A Magyar Névarchívum Kiadványai 16. Debrecen, Debreceni Egyetemi Kiadó.

HOFFMANN ISTVÁN-RÁCZ ANITA-TÓTH VALÉRIA 2018. Régi magyar helynévadás. A korai ómagyar kor helynevei mint a nyelvtörténet forrásai. Budapest, Gondolat Kiadó.

INCZEFI GÉZA 1970. Földrajzi nevek névtudományi vizsgálata. Makó környékének földrajzi nevei alapján. Budapest, Akadémiai Kiadó.

KÁLNÁSI ÁRPÁD 1996. Szatmári helynévtípusok és történeti rétegzödésük. A Debreceni Egyetem Magyar Nyelvtudományi Intézetének Kiadványa 67. Debrecen.

KÁZMÉr MiKLós 1957. Alsó-Szigetköz földrajzinevei. A Magyar Nyelvtudományi Társaság Kiadványai 95. Budapest.

KovÁCs Éva 2015. A Tihanyi összeirás mint helynévtörténeti forrás. A Magyar Névarchívum Kiadványai 34. Debrecen, Debreceni Egyetemi Kiadó.

KovÁCs Éva 2018. A Százdi alapitólevél mint helynévtörténeti forrás. A Magyar Névarchívum Kiadványai 48. Debrecen, Debreceni Egyetemi Kiadó.

LÖRINCZE LAJOS 1947. Földrajzineveink élete. Budapest, Néptudományi Intézet.

SzÖKE MELINDA 2015. A garamszentbenedeki apátság alapitólevelének nyelvtörténeti vizsgálata. A Magyar Névarchívum Kiadványai 33. Debrecen, Debreceni Egyetemi Kiadó.

\section{The Onomatosystematical Study of Toponyms in the Founding Charter of Garamszentbenedek}

The Founding Charter of Garamszentbenedek $(1075 /+1124 /+1217)$ is one of our key linguistic records as it features close to 280 toponyms. At the same time, it is interesting linguistically also because it is an interpolated charter, which means that the $11^{\text {th }}$-century charter was expanded with such parts in the $13^{\text {th }}$ century that 
had not been included in the original. I have associated the toponyms found in the charter with chronological layers based on clues related to historical linguistics, settlement history and other areas, whereby one of these layers is represented by the time of writing the original charter, the $11^{\text {th }}$ century, and the other with that of the interpolation, i.e., the $13^{\text {th }}$ century. I analyzed the toponyms of the Founding Charter of Garamszentbenedek from an onomatosystematical perspective by linking them with chronological layers. I included 131 name forms in my study, 82 names coming from the $11^{\text {th }}$-century layer and 49 from the $13^{\text {th }}$. The significant reduction in the number of names included in the study compared to the complete toponymic corpus of the charter may be explained by several reasons. During the analysis, I disregarded the multiple appearances of the names and considered them only once. I excluded those names from the analysis the reading of which is uncertain and I did not use those names either that were recorded in the charter only in Latin.

In the analysis, I first studied the proportion of civilizational and natural names. In the case of the $11^{\text {th }}$ century, I have found that this ratio was almost identical ( $48 \%$ civilizational, $52 \%$ natural names). However, in the case of names from the $13^{\text {th }}$ century, the proportion of natural names appeared to be higher, with $39 \%$ of the names being civilizational and $61 \%$ natural. The reason for such an increase may be that in the process of interpolation the names were complemented with their boundary descriptions, and thus newer natural names were added to the charter. I also examined the proportion of single-component and two-component names in the Founding Charter. Single-component names were present in a higher proportion in both chronological layers but the dominance of single-component names had decreased somewhat by the $13^{\text {th }}$ century. I also analyzed the toponyms of the Founding Charter of Garamszentbenedek from a functional-semantic perspective. I have found in the case of both chronological layers that most frequently the civilizational names were of a single-component type and they referred to the owner of the place. Names with a designating function also appeared in a significant proportion (as there are a lot of adapted names in the charter), along with names referring to people living there and the relationship of the place to other places. In the case of natural names, the highest proportion among name types was represented by hydronyms in the case of both chronological layers. Single-component names were typical in both the original and the interpolated parts of the charter in the case of natural names, but in the $13^{\text {th }}$ century the proportion of two-component natural names increased significantly compared to the $11^{\text {th }}$ century.

I also expanded the onomatosystematical study of the toponyms in the Founding Charter of Garamszentbenedek with the results of studies of other charters. I compared the original part of the charter with the Founding Charter of Tihany 
(1055) and the $11^{\text {th }}$-century section of the Founding Charter of Százd (1067), while the results of the interpolated charter with the Tihany Census (1211) and the $13^{\text {th }}$-century section of the Founding Charter of Százd (1267). As the first step of such a comparison, I examined the proportion of natural and civilizational names in the above charters, then I compared the ratio of single-component and two-component settlement names. The comparison has shown that settlement names are most frequently of the single-component type in the examined charters, while the natural names show a slight dominance of single-component names with the exception of the Founding Charter of Tihany. 